\title{
Investigation of Myxomycetes (Myxomycota) in South Amanos Mountains (Hatay-Turkey)
}

\author{
Hayri Baba*, Yücel Doğan \\ Department of Biology, Faculty of Arts and Science, Mustafa Kemal University, 31040, Antakya Hatay, Turkey. \\ "hayribaba_68@hotmail.com
}

Received: 14 May 2018

Accepted: 21 September 2018

DOI: $10.18466 /$ cbayarfbe. 423334

\begin{abstract}
Myxomycetes samples were collected from 10 different areas of South Amanos Mountains during 20132017. The samples were gathered from leaves, barks, litterfalls, decayed or unspoiled herbal materials. It was meant to try to develop myxomycetes sporophores by applying moist chamber culture to collected samples. In addition, myxomycetes, which grew up in their natural environment were obtained. As a result of field and laboratory studies 48 taxa belonging to 10 families and 18 genera were identified and added to Turkey myxobiota. Totally at 304 substrates 122 samples obtained, 7 myxomycetes were collected only from fields, 115 samples were developed in moist chamber culture in the laboratory.
\end{abstract}

Keywords: Myxomycetes, Diversity, Chorology, South Amanos Mountains - Hatay, Turkey.

\section{Introduction}

Myxomycetes or Mycetozoa; widely found in humid terrestrial ecosystems, associated with plants and plant debris, show various morphological and ecological similarities with fungi [1]. The vegetative phase is an aggregate of protoplasmic clusters of multiple nuclei called plasmodium. In the generative stage, there are sporadic haploid (n) spores with a number of chromosomes creates one or more sporophore. They continue their lives by feeding in phagotrophic manner with other microorganisms; such as bacteria, arcs, yeast groups, fungi, and cyanobacteria.

According to the latest classification system; Mycetozo is located in the kingdom Protista. Consists of 2 classes; Protostelia and Myxogastria, 6 teams; Protosteliida, Liceida, Echinosteliida, Trichiida, Stemonitida and Physarida. There are 998 species worldwide, with a total of 13 families and 64 genera [2], in Turkey 13 family 45 genera and 262 species have been identified [3].

In this study, It was targeted that determination of the Myxomycetes taxa spreading in the South Amanos Mountains, which border on Antakya, Samandağ and Arsuz districts, diagnose, substrate selectivity, morphological differences, climatic seasonal differences, to contribute to Turkey myxobiota and uncovering the essential wealth of our country.

\section{Materials and Methods}

\subsection{Study Area}

South Amanos Mountains is located within Hatay province borders. West of our study area involved the Gulf of Iskenderun and Arsuz, the east of Antakya and
Amik plain, the south of Samandağ, the north of Iskenderun and Belen counties (Figure 1). The average elevation of the area is about 1000 meters, the highest point is 1800 meters. It is approximately $36^{\circ} 08^{\prime}-36^{\circ} 31$ 'North latitudes and $35^{\circ} 47^{\prime}-36^{\circ} 15^{\circ}$ East longitudes. According to the Henderson (1961) quadrature system South Amanos Mountains is located within the square C13.

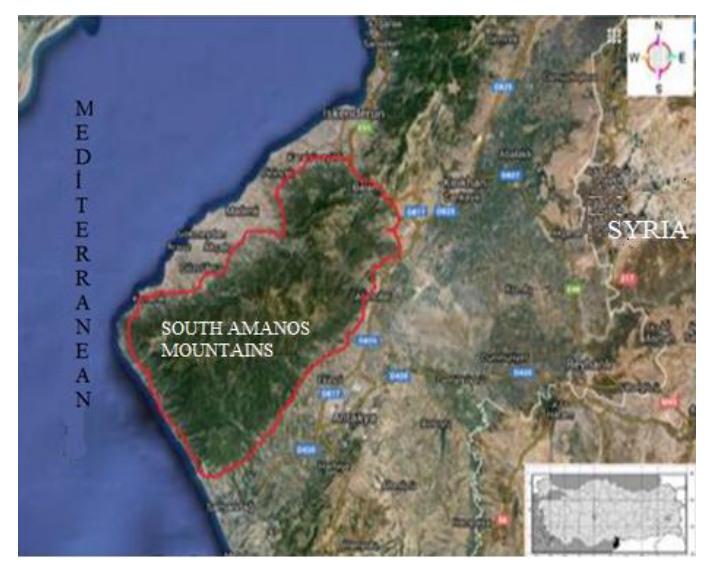

Figure 1. Research area.

Amanos Mountains has got 1580 plant taxa and 251 of which are endemic to Turkey. Typical vegetation of the region is Pinus brutia, Ajuga postii, Origanum amanum, Heleborus vesicarius, Arbutus andrahne, Cercis siliquastrum, Sorbus persica, Quercus cerris, Styrax officinalis, Arbutus unedo, Ostrya carpinifolia, Buxus sempervirens, Euonymus latifolius, Sambucus nigra, Sambucus ebulus, Acer platanoides, Corylus avellana, Tilia argentea, Cornus mas, Corpinus orientalis, Ilex colchica, Staphylea pinnata [4]. 


\subsection{Moist Chamber Technique}

Sterile filter paper is laid on petri dishes and plastic storage containers and the collected substrates were placed in these containers. Distilled water was added and waited 48 hours in summer and 24 hours in winter. Samples were checked on a stereo- microscope every two days and the sporophore developments in the life cycle of the myxomycetes members were noted and have tried to obtain sporophore $[5,6]$.

\subsection{Preparation of Fungarium Material}

Sporophores collected natural area or obtained with moist chamber technique in the laboratory is dried, with blotting paper in petri dishes in room conditions or 24 degree set-up tool. After drying fungarium material prepared. For fungarium material the middle part of cut cardboard parts slice of specimens partially placed together with the substrate and adhered to the surface and closed. The sample was prepared as fungarium material and stored in the laboratory of Department of Biology, Faculty of Science and Arts, Mustafa Kemal University in Hatay.

\subsection{Identification of Samples}

For the diagnosis of the samples a stereomicroscope and a light microscope with high resolution power were used.
General structure of fructification, shape, colour, macroscopical measurements, Capillitium and pseudocapillitium ornamentation, lime-limestone structure, Spores shape, measurements, ornamentations and colour, Columella morphology and measurements, stalk, hypothallus, peridium diagnosed and examined in detail. For temporary preparations; $3 \% \mathrm{KOH}$ solution or distilled water was used. In permanent preparations; Amman's lactophenol medium, Hoyer's medium or Hantsch's fluid was used. Myxomycetes samples were identified according to the respective references [7-13].

\section{Results and Discussion}

Between 2013-2017 at 10 stations in South Amanos Mountains 304 substrate samples collected and examined in the laboratory. Totally 122 samples were obtained. The diagnosis of the 122 samples; from natural environment 7 and the moist chamber technique 115 samples obtained. Belonging to 6 team, 10 families and 18 genera 48 species were identificated.

According to the distribution of 6 teams Trichiida and Physarida are the most common team (Figure 2). Protostelida and Echinosteliida which known to the least species in the world [2], are at least species in our study.

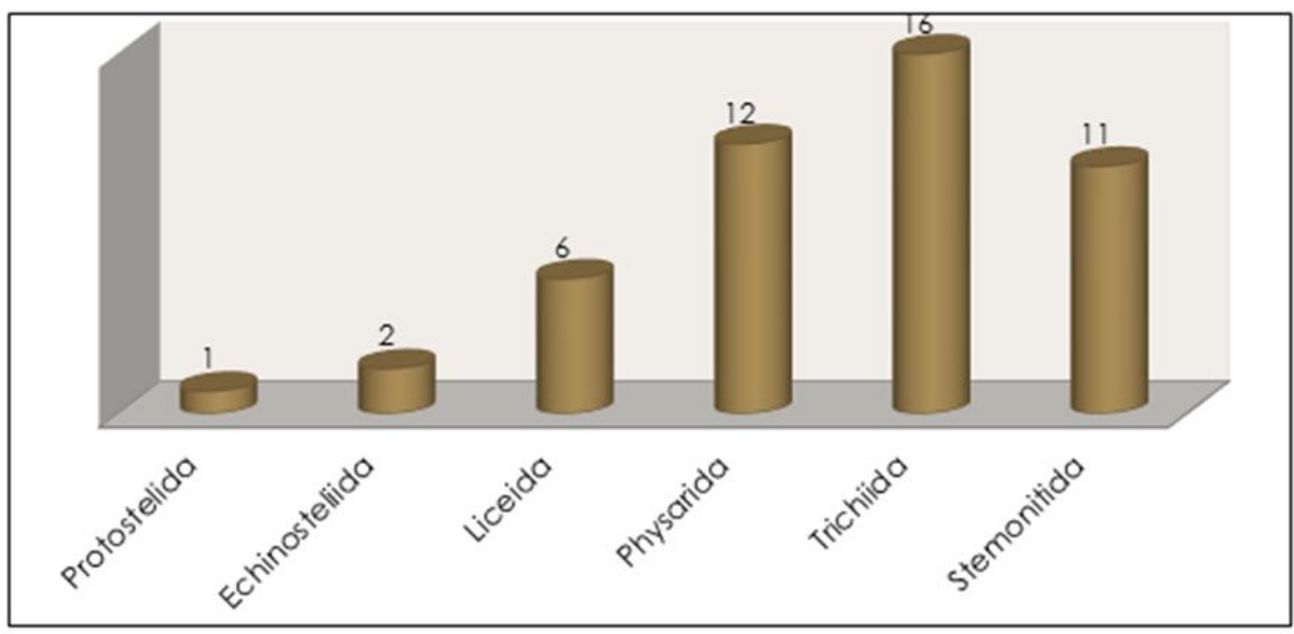

Figure 2. Team distributions of the detected samples.

According to the research result distribution of 10 family; Stemonitidaceae, Physaraceae, Arcyriaceae and Trichiaceae contains 35 species (Figure 3). This ratio is
$72.9 \%$ of all our samples. These percentage results are in parallel with many studies in our country and the world [14-19]. 


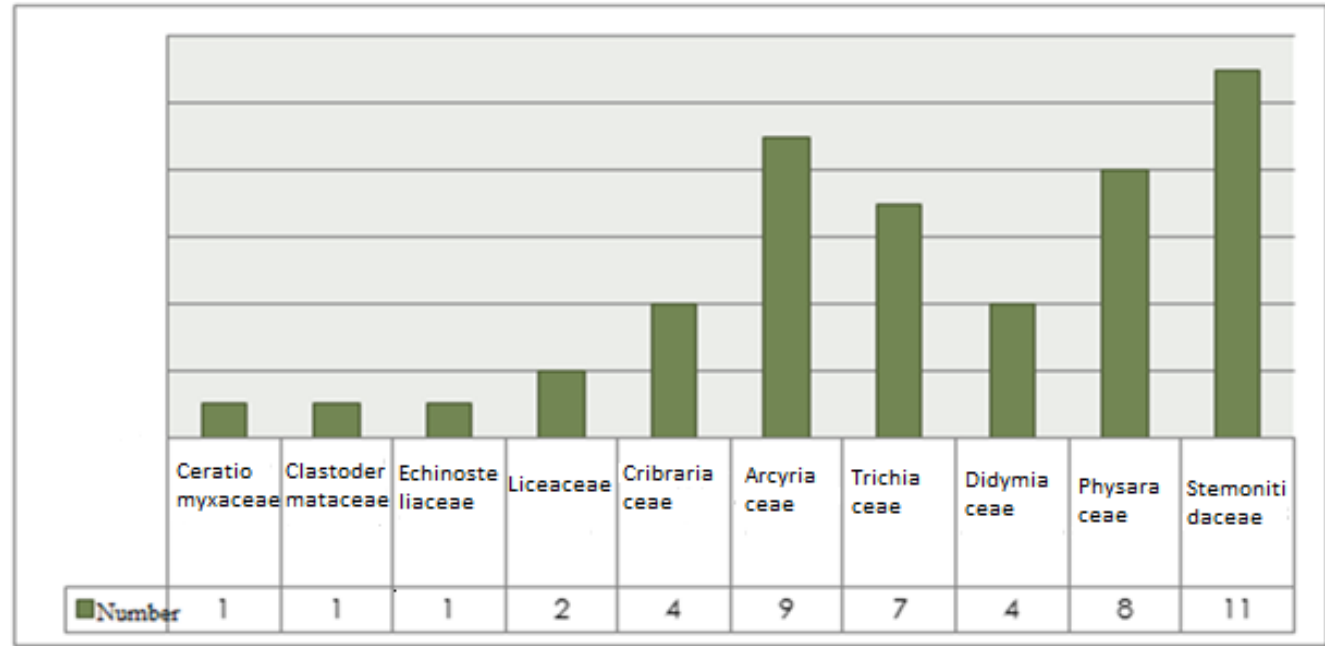

Figure 3. Family distributions of the detected samples.

The mean number of species per genus (S/G) was calculated from the data sets for the study area. Consequently, a low value for S/G implies a higher overall diversity than a high value. In our study area $\mathrm{S} / \mathrm{G}$ value is 2.66 and has got a higher diversity.

Abundance indices were assigned to all of the species represented among the collections from a particular study area (Figure 4). The abundance indices are Rare (for species represented by $<0.5 \%$ of the total number of all collections recorded from the study area being considered), Occasional (species represented by $>0.5 \%$ but $<1.5 \%$ of the total), Common (species represented by $>1.5 \%$ but $<3.0 \%$ of the total), and Abundant (species represented by $>3.0 \%$ of the total). Consequently, these indices are indications of the relative abundances of the various species found in a particular study area [20].

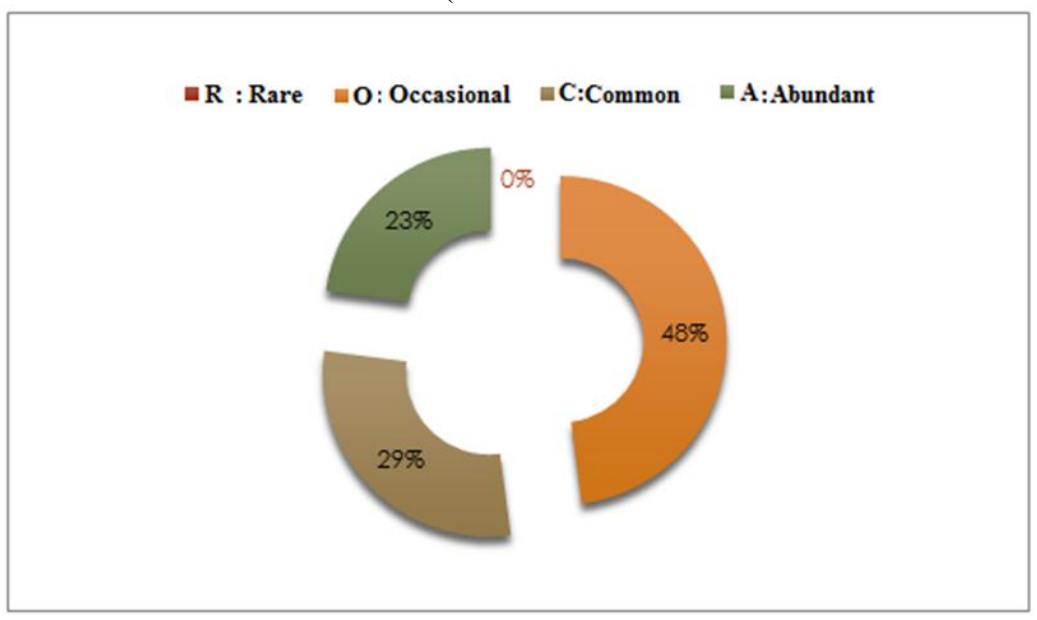

Figure 4. Distribution of samples by abundance levels.

When looking at the abundance ratios of the samples at common and $11(23 \%)$ were abundant species, we have 48 species 23 (48\%) were uncommon, 14 (29\%) were not found any rare species in our study area (Table 1).

Table 1. Frequency, locality, Obtaining methods and density data of taxa.

Species Frequency Localities Obtaining methods Occurrence

1. Ceratiomyxa fruticulosa 1

2. Clastoderma deberyanum 1

3. Echinostelium minutum 2

4. Licea minima

5. Licea kleistobolus

6. Cribraria cancellata

7. Cribraria microcarpa 3

8. Cribraria violacea 4

$\begin{array}{lll}\text { Çamlıyayla } & \text { N}^{*} & \text { O } \\ \text { Sahil } & \text { MCT } & \text { O } \\ \text { Kale } & \text { MCT } & \text { C } \\ \text { Karlısu Sahil Batıayaz } & \text { MCT } & \text { A } \\ \text { Ceylandere } & \text { MCT } & \text { O } \\ \text { Karlısu Ceylandere Sahil MCT } & \text { A } \\ \text { Sahil Karlısu Çamlıyayla } & \text { MCT } & \text { C } \\ \text { Batıayaz Ceylandere } & \text { MCT } & \text { A } \\ \text { Gülderen Karlısu } & & \end{array}$




\begin{tabular}{|c|c|c|c|}
\hline 9. Cribraria vulgaris & 2 & Sahil Büyükoba & MCT \\
\hline 10. Arcyria affinis & 1 & Karlisu & $\mathrm{MCT}$ \\
\hline 11. Arcyria cinerea & 15 & $\begin{array}{l}\text { Sahil Gülderen Karlısu } \\
\text { Vakıflı Kale Büyükoba }\end{array}$ & MCT \\
\hline 12. Arcyria incarnata & 2 & Kale Sahil & MCT \\
\hline 13. Arcyria insignis & 1 & Çamlıyayla & $\mathrm{MCT}$ \\
\hline 14. Arcyria minuta & 2 & Ceylandere Karlısu & $\mathrm{MCT}$ \\
\hline 15. Arcyria pomiformis & 3 & Sahil Seldiren & MCT \\
\hline 16. Perichaena corticalis & 1 & Batiayaz & $\mathrm{MCT}$ \\
\hline 17. Perichaena depressa & 1 & Sahil & $\mathrm{MCT}$ \\
\hline 18. Perichaena vermicularis & 1 & Kale & $\mathrm{MCT}$ \\
\hline 19. Trichia favoginea & 1 & Sahil & MCT \\
\hline 20. Trichia lutescens & 1 & Sahil & MCT \\
\hline 21. Trichia munda & 2 & Sahil Karlisu & $\mathrm{MCT}$ \\
\hline 22. Trichia persimilis & 1 & Gülderen & $\mathrm{MCT}$ \\
\hline 23. Trichia varia & 1 & Sahil & $\mathrm{N}$ \\
\hline 24. Trichia verrucosa & 2 & Gülderen Kale & $\mathrm{MCT}-\mathrm{N}$ \\
\hline 25. Didymium difforme & 5 & Vakıflı Sahil & $\mathrm{MCT}-\mathrm{N}$ \\
\hline 26. Trichia decipiens & 2 & Sahil & $\mathrm{MCT}$ \\
\hline 27. Didymium megalosporum & 1 & Ceylandere & $\mathrm{MCT}$ \\
\hline 28. Didymium squamulosum & 2 & Karlısu Gülderen & MCT \\
\hline 29. Didymium difforme & 1 & Batıayaz & MCT \\
\hline 30. Badhamia foliicola & 1 & Vakıflı & $\mathrm{MCT}$ \\
\hline 31. Fuligo septica & 1 & Karlisu & $\mathrm{MCT}$ \\
\hline 32. Craterium leucocephalum & $\imath 1$ & Kale & $\mathrm{N}$ \\
\hline 33. Physarum album & 11 & $\begin{array}{l}\text { Karlısu Kale Sahil } \\
\text { Batıayaz Büyükoba }\end{array}$ & $\mathrm{MCT}-\mathrm{N}$ \\
\hline 34. Physarum cinereum & 2 & Kale Çamliyayla & MCT \\
\hline 35. Physarum compressum & 1 & Sahil & MCT \\
\hline 36. Physarum contextum & 1 & Sahil & $\mathrm{MCT}$ \\
\hline 37. Physarum leucophaeum & 6 & Vakıflı Karlısu & $\mathrm{MCT}-\mathrm{N}$ \\
\hline 38. Collaria arcyrionema & 1 & Gülderen & $\mathrm{MCT}$ \\
\hline 39. Collaria lurida & 1 & Karlisu & MCT \\
\hline 40. Comatricha elegans & 2 & Gülderen Vakıflı & MCT \\
\hline 41. Comatricha ellae & 3 & Sahil & $\mathrm{MCT}$ \\
\hline 42. Comatricha nigra & 6 & Ceylandere Sahil Karlısu & $\mathrm{MCT}$ \\
\hline 43. Comatricha pulchella & 2 & Karlisu & $\mathrm{MCT}$ \\
\hline 44. Enerthenema papillatum & 1 & Batıayaz & MCT \\
\hline 45. Stemonitis axifera & 1 & Sahil & MCT \\
\hline 46. Stemonitis fusca & 2 & Sahil Karlısu & $\mathrm{MCT}$ \\
\hline 47. Stemonitis pallida & 2 & Sahil Batıayaz & $\mathrm{MCT}$ \\
\hline 48. Stemonitopsis amoena & 9 & Sahil Gülderen Batıayaz & $\mathrm{MCT}$ \\
\hline
\end{tabular}

( ${ }^{*}$; Natural samples, MCT: Moist Chamber Technique, Occurrence A: Abundant, C: Common, 0: Occasional and R: Rare [20].

Arcyria cinerea is registered as the most dense species with 15 samples in 6 localities. This species was found in different altitude, locations and different substrates in study area. This results also shows parallels with a lot of work in Turkey and world. Apart from this species, Physarum album (11) and Stemonitopsis amoena (9) are the most dense species. From the 7 natural samples, 3 species are dense, 3 species are rare, and 1 is common.

In our study, the Gymnosperm group plants substrates was exposed to Pinus sp. and Quercus sp. wood, crust and rubble have been seen as the most efficient materials. Apart from these, rarely Mycetozoa samples were obtained from plant materials such as Laurus nobilis, Ceratonia siliqua and Pistacia terebinthus (Figure 5). A large part of our samples were obtained from the materials of the Gymnosperm species, which are closely related to peer-reviewed studies in close proximity [16, 17]. The fact that the region is covered with dense pine and oak forest is an important influence in achieving this results. 


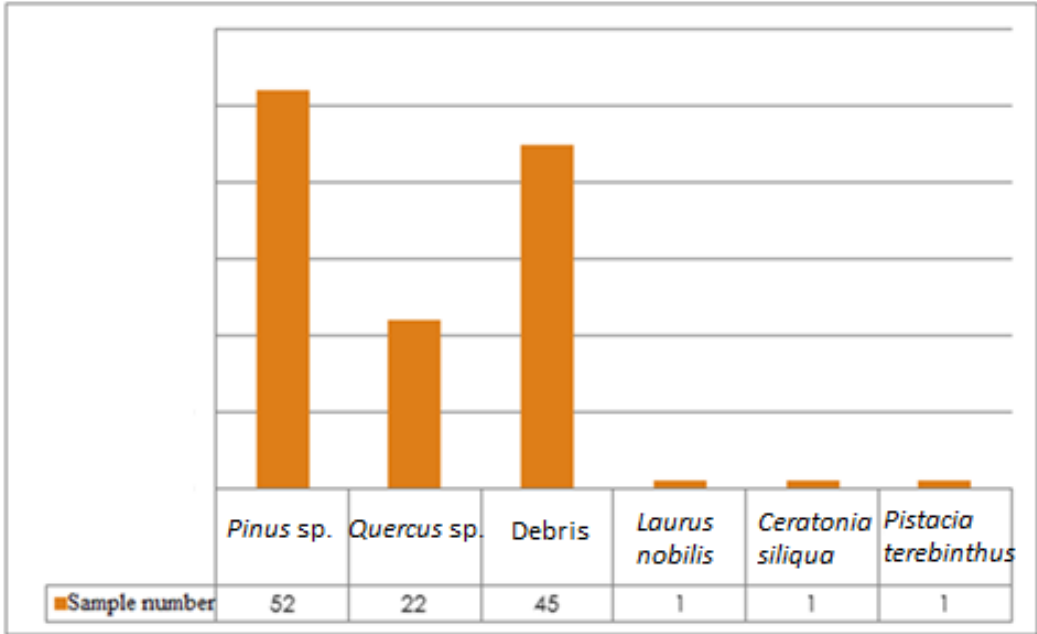

Figure 5. Number of samples according to substrate source.

Classification of 122 Mycetozoa members according to substrate preferences 86 species is Lignicolous, 33 Corticolous and 3 are Foliicolous (Figure 6). The substrate preferences of the Mycetozoa members are not very diverse, but they can be classified as Myxomycetes based on the properties of the preferred substrates.
Corticolous myxomycetes are benefit from the bark of the plant. Lignicolous myxomycetes are used to wood particles from plants. Foliicolous myxomycetes uses the leaves of the plants, Fimicolous myxomycetes prefer animal feces and Nivicolous myxomycetes prefer the extreme conditions of the specific substrate [16].

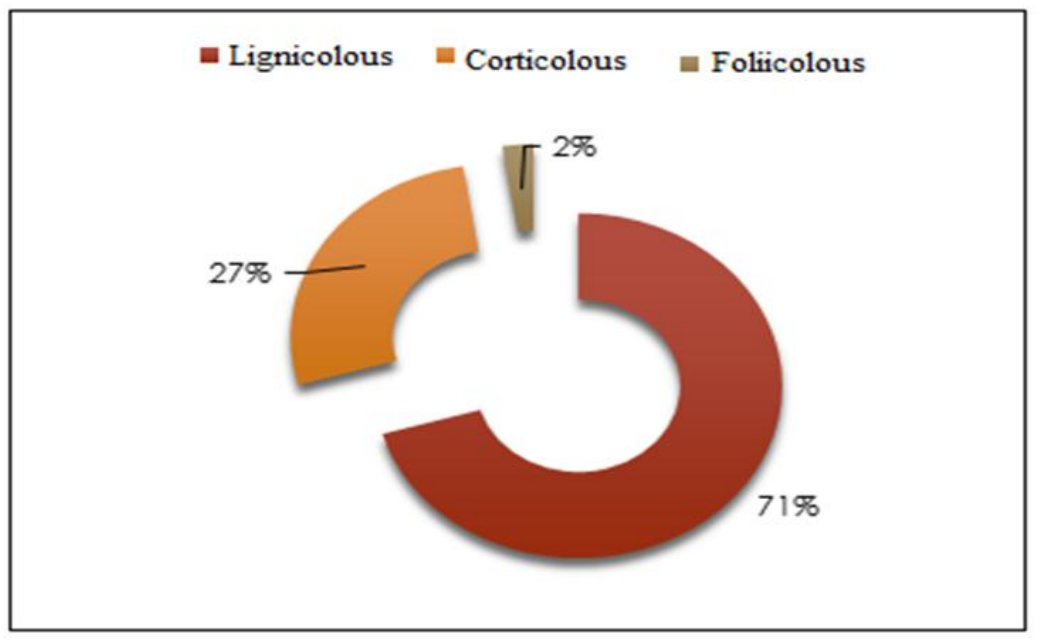

Figure 6. The distribution of the samples according to the kinds of substrate.

Land visits were made to 4 seasons of the year, so it is aimed to obtain species with different climatic requirements. Distribution of the obtained samples according to 4 season is Autumn 47, Winter 38, and Spring 29 Summer 8 (Figure 7). When the seasons of the samples are taken into consideration it is seen as a much less frequent example in summer. This includes extreme drought in summer, destructions and human activities besides the Moist chamber technique also caused the effect of factors such as mold decay, parasitism. and in the other three seasons it is known to be productive. 


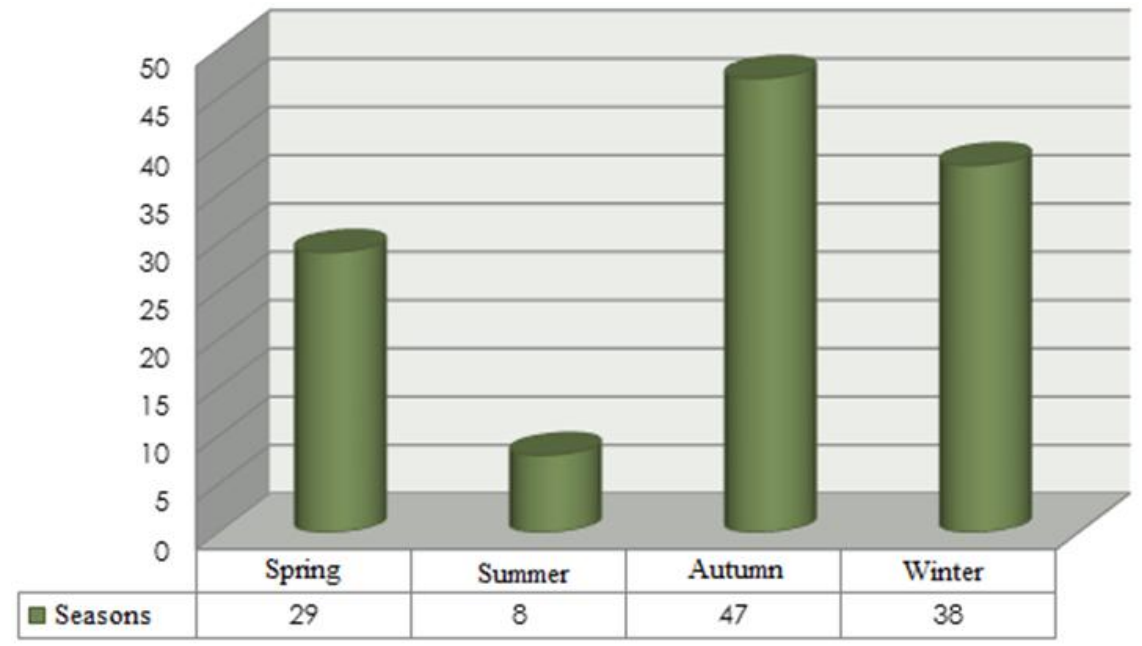

Figure 7. Distribution of samples by season.

Plasmodium is constitute the nutritional, growth and development, vegetative stage of myxomycetes. Plasmodium have different color configurations ranging from transparent, white, yellow, red, and even silver influenced by such factors as nutrient, light, temperature and $\mathrm{pH}$. In our study Trichiaceous plasmodium is seen 16 species, Protoplazmodium 8, Phaneroplazmodium 12 and Aphanoplazmodium 12 (Figure 8).

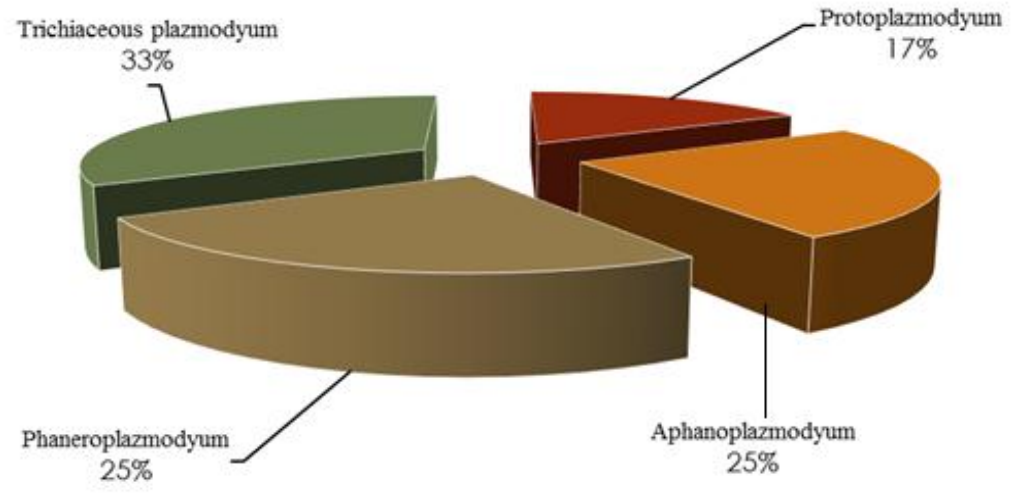

Figure 8. Distribution of detected samples according to plasmodium type.

Differences in sport ornamentations is an important criterion in classification of Mycetozoa. According to sports ornaments flying sports has got better adhesion to surfaces and also increases germination ability. When sports analyzed 27 species has got warty ornamentation, 14 reticulated and 7 spiny were detected (Figure 9). 


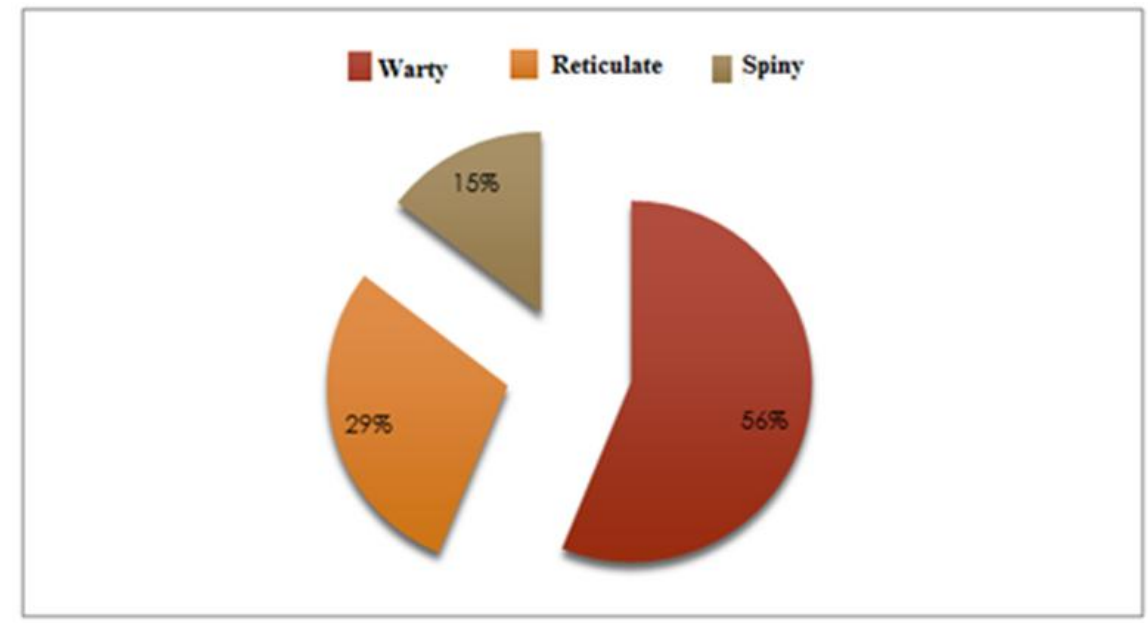

Figure 9. Distribution of detected specimens by sport type.

When our samples compare to the sporophore types Sporangium is the most intense sporophore type, while pseudoaethalium type sporophore is the most rare. 21 species has got sporangium, 14 aethalium, 8 plasmodiocarp and 5 pseudoaethalium (Figure 10).

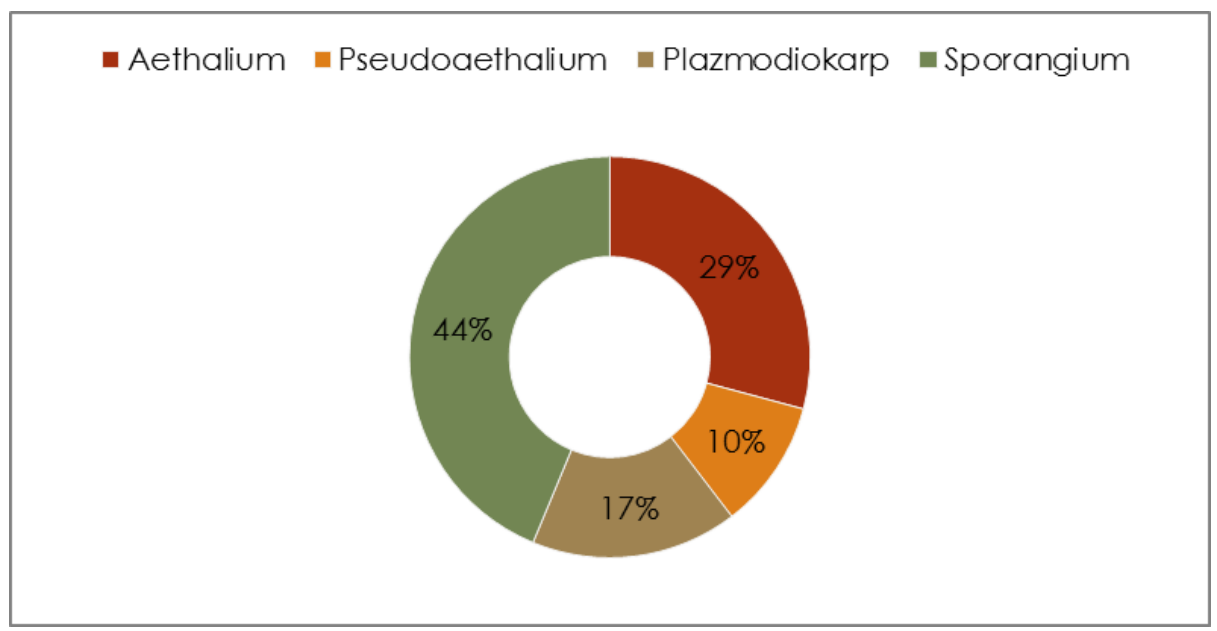

Figure 10. Distribution of detected samples according to sporophore type.

\section{Conclusion}

South Amanos Mountains, being covered with rich forest, flora and fauna. Due to the fact that different geographical and climatic characters are transitional regions and rich biodiversity the study area has got very rich myxobiota. The results obtained by our work support this. Collected samples and numbers are compared with the land locations; it is seen that species diversity is less in our land where interacting human factors. For example, while the Büyükoba station samples number were few, at Arsuz-Samandağ coastline a lot of samples were obtained, which is relatively far away from human settlements and covered with dense forest. In addition, the forest fires, which are repeated every year, hinder the biodiversity of the region along with myxobiota.

\section{Acknowledgement}

This study was prepared at Master thesis MKÜ Institute of Science and Technology Partment of Biology presidency at «Investigation of Myxomycetes (Myxomycota) in South Amanos Mountains (Hatay)». I would like to thank the MKÜ Scientific Research Projects commission (Project No: 15302) for financial support. This study was presented at IV. International Congress for Applied Biological Sciences 3-5 May 2018 Eskişehir as Oral presentation.

\section{References}

1. Martin, G,W, Alexopoulos, C,J, The Myxomycetes. University of Iowa pres, Iowa, 1969, pp. 560.

2. Lado, C, An on line nomenclatural information system of Eumycetozoa. Real Jardín Botánico, CSIC. Madrid, Spain. Last updated April 25, 2018. http://www.nomen.eumycetozoa.com.

3. Baba, H, Er A, Craterium dictyosporum: A new record of Myxomycetes from Hatay, Turkey. Acta Biologica Turcica, 2018, 31(1);33-35. 
4. Cakan, H, Byfield, A, Amanos Dağları', Türkiye'nin Önemli Bitki Alanı (Ed. N.Özhatay, A.Byfield ve S.Atay): WWF Türkiye yayını, İstanbul 2005. P: 254-257.

5. Baba, H, Myxomycetes of Mustafa Kemal University campus and environs. Turkish Journal of Botany, 2012, 36; 769-777.

6. Stephenson, S,L, Stempen, H, A Handbook of Slime Moulds. Timber Press, Portland, Oregon, 2000, pp. 183.

7. Thind, K,S, The Myxomycetes of India. I.C.A.R, New Delhi, 1977 pp. 421.

8. Martin, G,W, Alexopoulos, C,J, Farr, M,L, The Genera of Myxomycetes, Univ. Iowa Pres, Iowa, 1983, pp. 438.

9. Neubert, H, Nowotny, W, Baumann, K, Die Myxomyceten (Band I). Karlheinz Baumann Verlag Gomaringen, 1993, pp. 343.

10. Neubert, H, Nowotny, W, Baumann, K, Die Myxomyceten (Band II).Karlheinz BaumannVerlag Gomaringen, 1995, pp. 368.

11. Neubert, H, Nowotny, $W$, Baumann, K, Marx, H, Die Myxomyceten (Band III). Karlheinz BaumannVerlag Gomaringen, 2000 , pp. 391

12. Lado, C, Pando, F, Flora Mycologica Iberica. Vol. 2. Madrid Spain, 1997, pp. 323
13. Ing, B, The Myxomycetes of Britain and Ireland. The Richmond Publishing Co.,Slough, England, 1999, pp. 330.

14. Oskay, M, Tüzün, Ö, Kemalpaşa ve Çevresi (İzmir) Miksobiotasının Belirlenmesi. C.B.U. Journal of Science 2015, 11 (1), 59-68.

15. Ergül, C,C, Akgül, H Myxomycete Diversity of Uludağ National Park Turkey. Mycotaxon, 2011, 116:479.

16. Everhart, S,E, Keller, H,W, Life history strategies of corticolous myxomycetes: the life cycle, fruiting bodies,plasmodial types, and taxonomic orders. Fungal Diversity, 2008, 29, 1-16.

17. Stephenson, S,L, Kalyanasundaram, I, Lakhanpal, T,N, A comparative biogeographical study of myxomycetes in the midAppalachians of eastern North America and two regions of India, Journal of Biogeogr, 1993, 20, 645-657.

18. Baba, H, Özyiğit, İ,İ, Three new rare Myxomycetes (Mycetozoa) records from Hatay, Turkey. Fresenius Environmental Bulletin 2017, 26(8), 4907-4910

19. Ergül, C,C, Dülger, B, Akgül, H, Myxomycetes of Mezit stream Valley of Turkey. Mycotaxon, 2005, 92, 239-242.

20. Stephenson, S,L, A comparative species listing of myxomycetes from tropical (Philippines) and temperate (United States) forests. Mycosphere, 2014, 5(2), 299-311. 